how the Forest Products Research Laboratory solved this difficulty by its portable charcoal-burning kiln; and it followed up developments and exploitation of this beyond normal limits by seconding one of its officers to the Timber Control Department to supervise the erection and working of the kilns and by training operators. The other important subject mentioned is in connexion with plywood and the revision of the aircraft plywood specification, leading to simplification and the conservation of supplies. These activities on the part of the Laboratory have brought it into much closer relation to the timberusing industries and made them aware of its value to them

In 1943 the Board commenced to consider recommendations for post-war work of the Laboratory. As the director states, the necessity now exists of placing the Laboratory in a good position to meet the increasing requests by industry for advice, to make its results more effectively known, and to expand the resources of the Laboratory both in income and material. Detailed accounts of the work carried out in the years 1946 and 1947, together with $\operatorname{som} \theta$ interesting illustrations, complete the reports.

E. P. Stebring

\section{BIRD MIGRATION IN THE TRENT VALLEY}

$\mathrm{D}$ URING the autumn months of July, August, September and October in the years 1940-47, continuous observations of the movements of bird migrants were made by R. J. H. Raines along the Trent Valley in Nottinghamshire and on the extensive Nottingham sewage farms. These observations revealed that a substantial passage movement of a wide variety of species regularly takes place in the region. The facility with which movements are observed in the district is attributed to the narrowness of the valley and the situation of the sewage farms in its course as potential feeding and resting grounds (British Birds, 43, 140, 4 ; April 1950).

A total of 126 species of migrant birds has been recorded from the district during the years under observation. Of this number, ninety-three species have occurred regularly, many in extremely large numbers, and the remainder have been recorded as rare vagrants or of irregular occurrence.

The migratory movements were of four kinds : an exodus of local summer residents; an emigration of summer residents of more distant origin ; a passage migration of foreign birds and a local movement of some British resident species. The great majority of these movements occur on a south-westerly flight, but a large number of birds, most probably emigrants, move in an easterly direction; several species migrate from east to west.

It has been inferred that many migrants reach the Trent Valley by at least two main routes. One stream of migration arises on the Yorkshire coast in the region of Flamborough Head, crosses the East Riding to the Humber and then passes up the River Trent to reach the Trent Valley near Newark. Some proportion of migrants reaching Spurn Head cross the Humber mouth and probably turn inland on the North Lincolnshire coast, then pass over North Lincolnshire towards Lincoln and Newark, thus reaching the Trent Valley by a direct south-west course.
The two streams of immigrants meet at the mouth of Trent Valley, pass along the Trent through South Nottinghamshire and Derbyshire, leave the Trent and move through the region of Birmingham and South Staffordshire, most probably to the Severn Valley. It may be surmised that the passage continues to the south coast of Britain or the Bristol Channel.

The most important of the factors affecting inland migration is the direction and velocity of the wind. Opposing winds, unless strong, appear to be favourable to the progress of migration, whereas following winds are less favourable to the majority of migrants, though apparently necessary for the local occurrence of some species such as the wood-sandpiper.

\section{SOCIETY OF FORESTERS OF GREAT BRITAIN \\ ANNUAL GENERAL MEETING}

$\mathrm{T}$ its recent annual general meeting in Oban, the Society of Foresters of Great Britain unanimously awarded the Society's medal to Sir John Stirling Maxwell, in recognition of his pioneer work in planting peat land at Corrour and Fersit, which was the basis of the system now in general use by the Forestry Commission.

The following office-bearers and couneillors were elected : President, Prof. H. M. Steven, Department of Forestry, University of Aberdeen ; Vice-President, A. H. Gosling, director-general, Forestry Commission; Editor of Journal, R. W. V. Palmer (c/o Estate Office, Eastnor, near Ledbury, Herefordshire) ; Business Editor, J. A. B. Macdonald, silviculturist (north), Forestry Commission; Secretary and Treasurer, R. A. Galloway (8 Rutland Square, Edinburgh, 1); Auditor, D. L. Ferguson, Forestry Commission, Edinburgh ; Councillors, Prof. H. G. Champion, Imperial Forestry Institute, Oxford; Sir Henry Beresford.Peirse, director of forestry for Scotland; W. E. Hiley, manager, Dartington Woodlands, Ltd., South Devon; G. B. Ryle, conservator (private woods), Directorate for England; A. P. Long, director of forestry for Wales; Bruce Urquhart, technical officer, Cooperative Forestry Society (Scotland), Ltd., Edinburgh.

The meeting took place during the annual excursion, held this year in Argyll, with headquarters at the Great Western Hotel, Oban, in which about sixty members took part. Visits were paid to Inverliever and Barcaldine Forests of the Forestry Commission and to the Argyll Estates at Inveraray and Sir George Campbell's Cumlodden Estate. These visits brought out several points of importance: the remarkable rate of height growth and volume production particularly of the Pacific coast species, sitka spruce, Abies grandis and Tsuga heterophylla; the problems of spacing, time of first thinning and degree and interval of thinning arising out of this growth ; the problem of extraction under certain conditions in the west, arising out of the broken nature of the ground, the high rainfall and peat conditions.

At Barcaldine Forest the members saw a magnificent clump of Douglas firs to which the name of "Sutherland's Grove" was given in recognition of the work of Sir John Sutherland, who was the first assistant commissioner for Scotland under the Forestry Commission and was associated with Barcaldine both before and after its acquisition by the State. 